Article

\title{
Profitability of Small-Scale Fisheries in Elmina, Ghana
}

Denis W. Aheto ${ }^{1, *}$, Noble K. Asare ${ }^{1}$, Belinda Quaynor ${ }^{2}$, Emmanuel Y. Tenkorang ${ }^{3}$, Cephas Asare ${ }^{4}$ and Isaac Okyere ${ }^{1}$

1 Department of Fisheries and Aquatic Sciences, University of Cape Coast, PMB, Cape Coast, Ghana; E-Mails: nasare@ucc.edu.gh (N.K.A.); iokyere@ucc.edu.gh (I.O.)

2 Marine Fisheries and Research Division (MFRD), P.O. Box BT 62, Tema, Ghana;

E-Mail: santabe187@gmail.com

3 Institute for Development Studies (IDS), University of Cape Coast, PMB, Cape Coast, Ghana; E-Mail: eytenkorang@yahoo.co.uk

4 WorldFish Center, Jalan Batu Maung, Batu Maung, 11960 Bayan Lepas, Penang, Malaysia; E-Mail: C.Asare@worldfishcenter.org

* Author to whom correspondence should be addressed; E-Mail: daheto@ucc.edu.gh; Tel.: +233-2410056; Fax: +233-332132709.

Received: 22 August 2012; in revised form: 4 October 2012 / Accepted: 10 October 2012 / Published: 24 October 2012

Abstract: In order to achieve sustainable fishing livelihoods in coastal communities, data on profitability of small-scale fisheries relative to fish species hauled and gear types used by fishermen is required as part of a broader fisheries management strategy. This study was undertaken with this in mind. Interviews were conducted among 60 fishermen between February and March 2010. Economic assessment of small-scale fishing activities were done using questionnaires based on direct market pricing and contingent valuation methods. The results indicate that highly profitable fish species include Epinephelus aeneus, Sparus caeruleostictus, Dentex angolensis and Lutjanus goreensis valued at US\$2.97, US\$2.87, US\$2.85 and US\$2.63 per kilogram respectively. The less profitable species include Dasyatis margarita, Caranx crysos and Sardinella aurita valued at US\$0.34, US\$0.66 and US\$ 0.85 per kilogram respectively. Although Sardinella aurita was among the less valuable fish species, it was the main species driving profits for the fishermen due to its high share volume among the fish catches. Findings from this study suggest high rates of exploitation, in that stocks generally cannot provide for increased economic return in the face of increased investment. This is a clear indicator that the open-access nature of Ghanaian fisheries is not sustainable, and management reform is well overdue. 
Keywords: small-scale fisheries; economic assessment; fishing livelihoods; Elmina

\section{Introduction}

Small-scale fishing or artisanal fishing ranges from sedentary to migrant fishers or communities, from part-time to full-time fishing activity, from subsistence to commercial fishing, from nonadvanced and non-differentiated to highly differentiated and specialized form of fishing [1]. Globally, small-scale fishers operate in some of the biologically richest and most productive waters on earth, often in tropical coastal zones [2]. In small-scale fishing, coastal ethnic communities use traditional techniques which are often but not always intensive compared to modern industrial fishing techniques [1]. The activities of the small-scale fishing communities are often aimed at supplying fish and fishing products to local and domestic markets and also for household consumption [3]. The small-scale fishing sector provides direct employment to millions of people, and indirect employment to millions more. FAO in 1998 reported that $98 \%$ of fishing jobs worldwide come from small-scale fishing [2].

In developing countries, fish provides about 19 percent of the protein intake [4]. In addition to nutrition, small-scale fishing activity in Africa plays a vital role in some economic activities including trade [5]. The basic technologies used by small-scale fishers in Africa distinguish them from large-scale commercial fishing operations. Small-scale fishers have generally smaller boats and gears, and land smaller quantities of fish than large-scale commercial fishing boats. Along the West African coast, large dug-out wooden canoes are the most commonly used by small-scale fishers. These fishers in this region also share socio-cultural and institutional characteristics such as higher population growth which are linked to heavy demands of labor for fishing and fishing related activities [5]. Ghana has a long history as a small-scale fishing country since the 1700s and 1800s [6,7]. Small-scale fishing in Ghana is characterized by the use of purse seine nets, beach seine net, set nets, drifting gillnets and hooks and lines, all operated from dug-out canoes. There are over 11,200 canoes and more than 124,000 fishers operating actively from over 300 landing sites located along the entire $550 \mathrm{~km}$ length of the coastline of Ghana. About 50 percent of these canoes are powered by outboard motors with engine power of up to $40 \mathrm{hp}$ [8].

In Ghana, the fishing sector employs $2.5 \%$ of the total population, contributing about $20 \%$ to the total labor force [9]. The small-scale fishers provide the majority of the national fisheries catch with the marine sub-sector delivering more than 80 percent of the total catch [5]. Fish is usually a cheaper and an appreciated source of protein [10]. In addition, the Ghana living-standards survey, which relies on expenditure levels revealed that coastal fishing communities in Ghana are among the poorest in the country. Therefore, a study on the valuation of gains of small-scale fishers is important in order to address the poverty situation in fishing communities as well as open up a debate on the sustainability of coastal fisheries in general [5].

The Elmina fishing harbor in the Central Region is the third largest fish landing site in Ghana after Tema and Sekondi harbors. Whilst the fisheries activities at Elmina are largely artisanal, those of Tema and Sekondi are predominantly oriented toward semi-industrial and industrial fishery. Regardless of 
the artisanal nature of fisheries activities in Elmina, it contributes about 15\% of the country's total fish output [11]. Therefore, Elmina significantly contributes not only to local livelihoods and economy of Elmina, but also to the national fisheries GDP. As such, Elmina presents an ideal site for this investigation. Being a historic fishing community where fishing dates back to the 1400s [12], the Elmina fish landing harbor which is built along the bank of the Benya lagoon provides a very good landing site for all types of canoes and small semi-industrial boats engaged in traditional fisheries. With a population size of 32,819 [13], Elmina serves as the center for several other fishing related and commercial activities. A canoe frame survey in 2004 found that there were 2632 fishermen and 231 canoes operating in the town [8]. Some semi-industrial vessels are also involved in the fishing operation. Furthermore, the Elmina 2015 Strategic report [11] reveals that about $75 \%$ of the estimated population of Elmina derive their livelihood directly from fishing or other activities that depend on it such as processing and trading of fish and canoe building.

The key objective of this paper is to estimate the profitability of small-scale fisheries to fishermen in relation to fish species hauled and gear types used in Elmina in the Central Region of Ghana.

\section{Methods}

The study was conducted at Elmina $\left(5^{\circ} 5^{\prime} 0^{\prime \prime} \mathrm{N} 1^{\circ} 21^{\prime} 0^{\prime \prime} \mathrm{W}\right)$, a major coastal fishing community in the Komenda-Edina-Eguafo-Abrem (KEEA) district in the Central Region of Ghana (Figure 1). The fisheries industry at Elmina involves the use of purse seine nets, hooks and lines, bottom trawls and drift nets. Sixty (60) fishermen were conveniently selected at the landing site at Elmina for a questionnaire survey between February and March 2010. The focus of the survey was to determine the investment cost in relation to the fishing gear and other equipment; quantities of fish species hauled and prevailing prices. The operational cost of each fishing trip was calculated based on cost incurred on gear (e.g., canoe, net and outboard motor) as well as food and fuel. The cost of the gears was based on the hiring rate at the time and duration of use. The cost of food and fuel was determined by the cost price per unit and the quantity utilized. It is important to note that in the informal sector (especially in fishing communities in West Africa), valuation of gains is not based on labor cost. Fish species landed by fishermen were identified using an identification manual [14], separated and weighed in kilograms $(\mathrm{kg})$. Fish species landed with respect to type of gear used were also documented. The profitability of fishing operations were derived from their fish haul based on direct pricing (market price at the time of fish landing) and contingent valuation techniques (fishermen's willingness to accept a price per $\mathrm{kg}$ ). The former technique followed the traditional market methods and estimated value according to the prevailing market forces (demand and supply). The latter quantified monetary gains of the fish resource based on knowledge of the quantity of fish hauled within a defined time frame, and how much fishermen were willing to accept as price per kilogram of fish. The economic value of various fish species was assessed using Equation (1) [15].

$$
\operatorname{DUV}=\sum_{i=0}^{n}(P i * Q i-C i)
$$


where:

DUV $=$ Direct Use Value; $P_{i}=$ Price; $Q_{i}=$ Quantity of fish landed; $C_{i}=$ Cost of fishing operations; $i$ refers to the item under description (various fish species in this context); $n=$ Total number of fishermen.

Figure 1: Map of study area indicating fishing landing site at Elmina, Ghana.

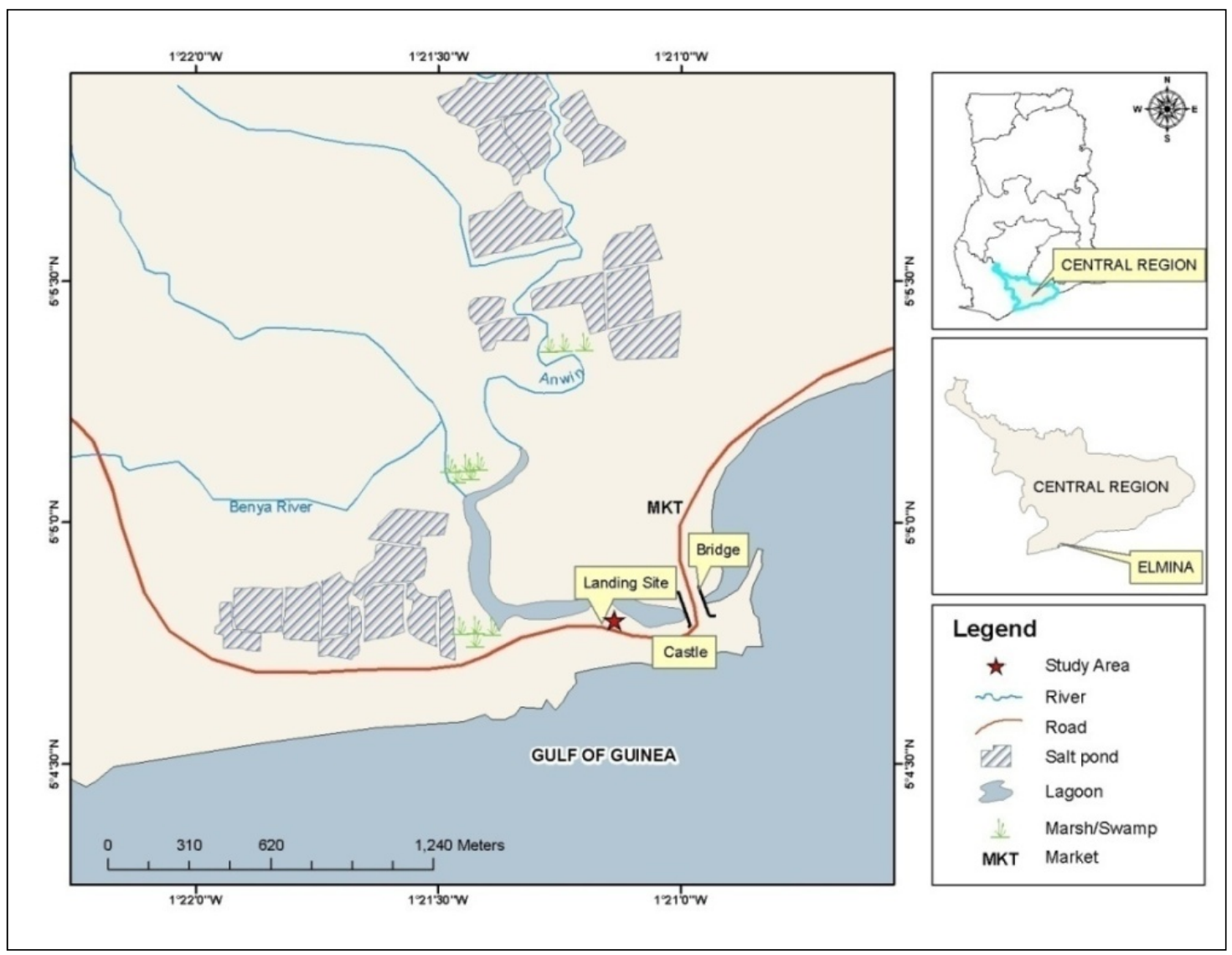

The test of significant correlation between the average cost and income per gear type was calculated according to Equation 2 [16].

$$
\mathrm{t}_{\text {obtained }}=\mathrm{r} \sqrt{ }\left(\mathrm{n}-2 / 1-\mathrm{r}^{2}\right)
$$

where:

$\mathrm{t}_{\mathrm{obtained}}=$ confidence interval in the student's $\mathrm{t}$ distribution obtained from the data

$r=$ correlation coefficient obtained

$\mathrm{n}=$ number of pairs of data used to run the correlation test

The $t_{\text {obtained }}$ for each correlation coefficient was then compared with critical $t$ values obtained from the student's t distribution at specified levels of significance and degrees of freedom. 


\section{Results and Discussion}

\subsection{Fish Species Landed and Fishermen Involvement}

The analysis reveals that Sardinella aurita constituted the most dominant fish species landed by $16 \%$ of the fishermen. This was followed by Dentex angolensis and Epinephelus aeneus, each represented by $15.4 \%$ of the fishermen. Caranx crysos and Sepia officinalis were among the least common fish species hauled by the fishermen. Comparing the number of fishermen hauling particular fish species and the amount of fish landed, the $S$. aurita was found to be the most hauled fish species by the majority of fishermen (Table 1).

Table 1. Quantities of fish species landed during the study period and number of fishermen in the fishery.

\begin{tabular}{lcccc}
\hline Fish species & $\begin{array}{c}\text { No. of } \\
\text { fishermen * }\end{array}$ & $\begin{array}{c}\text { Percentage of } \\
\text { fishermen ** }\end{array}$ & $\begin{array}{c}\text { Quantity of } \\
\text { catch (kg) }\end{array}$ & $\begin{array}{c}\text { Percentage } \\
\text { of catch }\end{array}$ \\
\hline Sardinella aurita & 28 & 16.0 & 30,275 & 30.9 \\
Dentex angolensis & 27 & 15.4 & 10,400 & 10.6 \\
Epinephelus aeneus & 27 & 15.4 & 9950 & 10.2 \\
Pseudotolithus senegalensis & 12 & 6.9 & 9500 & 9.7 \\
Sepia officinalis & 1 & 0.6 & 7550 & 7.7 \\
Sparus caeruleostictus & 16 & 9.1 & 6525 & 6.7 \\
Brachydeuterus auritus & 6 & 3.4 & 5200 & 5.3 \\
Elegatis bipinnulata & 13 & 7.4 & 4100 & 4.2 \\
Dentex congoensis & 9 & 5.1 & 3125 & 3.2 \\
Galeoides decadactylus & 4 & 2.3 & 3000 & 3.1 \\
Pagellus bellottii & 7 & 4.0 & 2800 & 2.9 \\
Lutjanus goreensis & 7 & 4.0 & 2275 & 2.3 \\
Auxis thazard & 6 & 3.4 & 1925 & 2.0 \\
Dasyatis margarita & 3 & 1.7 & 825 & 0.8 \\
Caranx crysos & 1 & 0.6 & 500 & 0.5 \\
Scomberomorus tritor & 8 & 4.6 & 125 & 0.1 \\
\hline Total & & $\mathbf{1 0 0}$ & $\mathbf{9 8 , 0 7 5}$ & $\mathbf{1 0 0}$ \\
\hline
\end{tabular}

* No. of fishermen used as a proxy for fishing effort. Data is based on multiple responses; ** Relative percentage of fishermen who landed each of the listed species.

The observed landings of Sardinella aurita in very high quantities (30.9\% of total catch) by most fishermen could be attributed to the local upwelling conditions at the time of the study. This period coincides with the lean upwelling season in Ghana.

In addition, the commercial abundance of the species may also have impacted on its value making it an affordable source of protein. During these upwelling seasons, $S$. aurita are in abundance and most often the method for their preservation is limited to smoking; therefore, if the market price per $\mathrm{kg}$ is not lowered, the catch would remain unsold and go to waste. Some fish species such as C. crysos and D. margarita were hauled in low quantities by few fishermen giving the indication of either dwindled 
stocks or these species are not actively targeted by the fishermen. However, Dentex spp. are targeted by relatively high number of fishermen even though the percentage catches are not very high.

\subsection{Economic Assessment of the Fishery}

The direct use value analysis was applied to estimate the market price per $\mathrm{kg}$ and incomes (gross and net incomes) of some fish species landed at Elmina. Table 2 shows the income, operational cost, and value per $\mathrm{kg}$ of fish species landed. The most valuable fish species landed include Epinephelus aeneus, Sparus caeruleostictus, Dentex angolensis, and Lutjanus goreensis valued at US\$2.97, US\$2.87, US\$2.85 and US\$2.63 per kg respectively (Table 2). The high value of these groups of fishes may be probably due to higher demand by consumers that could lead to over-exploitation by fishermen. Auxis thazard, Elegatis bipinnulata, Pagellus bellottii and Sardinella aurita could be classified as being among moderately valuable fish species, valued at US\$2.11, US\$2.06, US\$1.89, and US\$0.85 per kg respectively. Sepia officinalis was the least landed fish species with only $0.6 \%$ of the total number of fishermen hauling this species, representing $0.1 \%$ of total fish catch for the month (Table 2).

Table 2. Income, operational cost, and value per kg of fish landed during the study period.

\begin{tabular}{lccc}
\hline Fish species & $\begin{array}{c}\text { Income } \\
\text { (US\$/kg) }\end{array}$ & $\begin{array}{c}\text { Operational cost } \\
\text { (US\$/kg) }\end{array}$ & $\begin{array}{c}\text { Value } \\
\text { (US\$/kg) }\end{array}$ \\
\hline Epinephelus aeneus & 3.2 & 0.23 & 2.97 \\
Sparus caeruleostictus & 3.1 & 0.23 & 2.87 \\
Dentex angolensis & 3.09 & 0.24 & 2.85 \\
Lutjanus goreensis & 2.9 & 0.28 & 2.63 \\
Dentex congoensis & 2.75 & 0.18 & 2.57 \\
Sepia officinalis & 3.14 & 0.71 & 2.43 \\
Auxis thazard & 2.32 & 0.21 & 2.11 \\
Elegatis bipinnulata & 2.32 & 0.26 & 2.06 \\
Pagellus bellottii & 2.16 & 0.27 & 1.89 \\
Brachydeuterus auritus & 0.92 & 0.05 & 0.86 \\
Sardinella aurita & 0.9 & 0.05 & 0.85 \\
Scomberomorus tritor & 0.81 & 0.06 & 0.75 \\
Caranx crysos & 0.71 & 0.06 & 0.66 \\
Pseudotolithus senegalensis & 0.7 & 0.08 & 0.62 \\
Galeoides decadactylus & 0.7 & 0.09 & 0.61 \\
Dasyatis margarita & 0.52 & 0.18 & 0.34 \\
\hline
\end{tabular}

The economic values of some fish species hauled by the fishers were not dependent on the availability or patronage (demand and supply) of consumers but probably on the quality (i.e. taste) of the fish and cost of the fishing gear. The species with the most return per kg was the Epinephelus aeneus; valued at US\$2.97/kg followed by Sparus caeruleostictus with US\$2.87/kg (Table 2). These are the white grouper and sea bream respectively and are considered high-grade fish, hence the high return. The least valuable species landed include Dasyatis margarita, Pseudotolithus senegalensis and Caranx crysos valued at US\$0.34, US\$0.62 and US\$0.66 per $\mathrm{kg}$ 
respectively (Table 2). These species were generally characterized by low return on investment and this could be attributed to high investment cost and low market demand. These species could be considered as incidental catch/by-catch that are retained because they are saleable at giveaway prices to increase profit margins.

The Ghanaian fishery is characterized by the open-access system. With this form of fishery, the individual receives all of the economic benefits accruing from the fisheries. The resulting stock depletion is shared among all resource users and this eventually results in the tragedy of the commons [17]. The consequences of such system are that fishermen will continue to enter the fishery sector as long as revenues minus costs remain above zero, until ultimately the net revenue of the entire fleet is zero-the bionomic equilibrium [18]. At this equilibrium the resource is depleted as far as economics will allow and fishermen will move to alternative fisheries, resulting in the sequential depletion of fish stocks [19].

The relationship between the cost and income made on the hauled fish and the type of gear used was examined. The distribution is shown in Table 3. However, on the part of fishermen, there is the risk that higher investment may not necessarily lead to higher income (Table 3) due to the weak negative correlation observed between investment and income made. This information strongly suggests that target fishing of these high value species using the hook and line method is likely to be unsustainable.

Table 3. Relationship between the cost and income per fish species relative to type of gears used.

\begin{tabular}{llccc}
\hline Type of gear & Fish species & $\begin{array}{c}\text { Average } \\
\text { operational } \\
\text { cost (US\$) }\end{array}$ & $\begin{array}{c}\text { Average } \\
\text { income } \\
\text { (US\$) }\end{array}$ & $\begin{array}{c}\text { Correlation } \\
\text { Coefficient of } \\
\text { cost/income analysis }\end{array}$ \\
\hline Purse seine net & Sardinella aurita & 71.43 & 913.9 & \multirow{2}{*}{0.809} \\
& Elegatis bipinnulata & 80.36 & 650.41 & \\
& Caranx crysos & 28.57 & 328.57 & -0.0601 \\
Hook \& line & Dentex angolensis & 94.36 & 1096.12 & \\
& Epinephelus aeneus & 86.07 & 1093.3 & \\
& Dentex congoensis & 63.36 & 891.01 & \\
& Lutjanus goreensis & 90.14 & 853.74 & -0.1089 \\
& Sparus caeruleostictus & 108.33 & 756.97 & \\
& Pagellus bellottii & 95.02 & 1168.82 & \\
\hline Bottom trawl net & Pseudotolithus senegalensis & 66.22 & 490.33 & \\
& Dasyatis margarita & 48.61 & 94.25 & -1 \\
\hline Drift net & Galeoides decadactylus & 72.92 & 455.65 & \\
& Brachydeuterus auritus & 50.79 & 746.86 & \\
& Sepia officinalis & 89.29 & 303.57 & \\
\hline & Scomberomorus tritor & 58.56 & 708.41 & \\
& Auxis thazard & 67.46 & 676.59 & \\
\hline
\end{tabular}

However, both $A$. thazard and $P$. bellottii were hauled using drift net and hook and line fishing respectively with both showing negative correlation between investment and returns, suggesting that the higher the investment on this species the lower the return made. A. thazard showed a strong negative correlation between investment and returns, indicating that for a unit increase in investment 
the return also decreased by the same amount and vice versa. The bionomic equilibrium has shown that any stock that attracts low investment costs compared with revenues accrued, will be overexploited and overcapitalized or, in extreme cases, will become commercially extinct [17].

Although the $S$. aurita is ranked as one of the bottom $50 \%$ valuable species, the fishermen still concentrated on it since it appeared to bring in more revenue due to its abundance, cheaper fishing method (purse seine or "watsa") and the readily available consumer market. The correlation between the average operational cost incurred and average income per gear type used was positive (Table 3).

\subsection{Analysis of Cost and Income Relative to Gears Used}

For Sardinella aurita and Elegatis bipinnulata, investments made using the purse seining correlates positively with income made (Table 3 ). This suggests that the higher the investments the higher the returns and vice versa. This may be attributed to the mode of fishing, i.e., purse seining which targets shoal of fish occurring in large quantities. For example, the Sardinella aurita (sardines) was landed in high quantities by $16 \%$ of the respondent (Table 1) representing $30.9 \%$ of the total catch by respondents (Table 2).

Both Dasyatis margarita and Pseudotolithus senegalensis showed weak negative correlation between investment and returns, indicating that the higher the investment the lower the returns made but Caranx crysos showed positive correlation between investment and returns (Table 3). The observation suggests that $C$. crysos is a least valuable and scarce fish species. D. margarita recorded very low value and was one of the fish species hauled by the bottom trawl method with weak negative correlation of 0.1 (Table 3), hence the higher the investment cost, the lower the income made on the fish hauled.

It constituted $0.8 \%$ of the total catch with $1.7 \%$ of respondents hauling this species. The correlation between the average operational cost incurred and average income per gear type used were investigated (Table 3). In contrast to the others, a positive correlation coefficient of 0.809 was obtained for the purse seine net. This means that the higher the cost incurred on the harvest, the higher the income made. The Sardinella species was among this group of fishes. However, the $t_{\text {obtained }}$ for the correlation coefficient for the purse seine was 1.3762 and the $t_{\text {critical }}$ at 5 percent significance and 1 degree of freedom was 12.706 . This shows that the observed positive correlation between the average operational cost incurred and average income per gear type used was statistically not significant. This observation may be due to the small number of data set obtained.

Bottom trawl net and the hook and line showed a weak negative correlation between the cost and income of the species, that is, the higher the cost, the lower the income made on the harvest. The Epinephelus aeneus was hauled by the hook and line method. But for the drift net, there was perfect negative correlation between the cost and the income meaning that anytime the cost increased by a unit, the income decreased by a unit and vice versa. The correlation coefficients obtained for these gear types also tested as statistically not significant. This shows a typical case of increased fishing effort that is not commensurate with fish catches and economic returns. This probably indicates declining fish catches or overfishing in line with fish catch statistics in recent years [12]. 


\section{Conclusions}

The objective of this study was to estimate the profitability of small-scale fisheries to fishermen in relation to fish species hauled and gear types used in Elmina in the Central Region of Ghana. Generally, small-scale fishing is profitable with respect to purse seining due to the high share volume of Sardinella aurita hauled even though it is not a highly priced fish species. Although the volume landed for other fish stocks such as Epinephelus aeneus, Sparus caeruleostictus, Dentex angolensis, and Lutjanus goreensis were low, they were very profitable for fishermen due to their high market values. The tendency for over-exploitation of these highly priced fish species is rife due to this observation. Dasyatis margarita, Pseudotolithus senegalensis and Caranx crysos may however be incidental or by-catches.

It is recommended that concerted efforts should also be made into looking at value addition and development of taste through processing of the less valuable species to increase the net return per effort to fishermen hauling them. Generally, the results strongly suggest very high rates of exploitation or depletion, in that stocks cannot provide an increased economic returns in the face of increased investment except for a very few species such as $S$. aurita. This is a clear indicator that the open-access nature of Ghanaian fisheries is not sustainable, and management reform is well overdue.

\section{Conflict of Interest}

The authors declare no conflict of interest.

\section{References}

1. Demuynck, K.; DETMAC Associates. The Participatory Rapid Appraisal on Perceptions and Practices of Fisher-folk on Fishery Resource Management in an Artisanal Fishing Community in Cameroon; FAO: Cotonou, Benin, 1994; p. 32.

2. Schorr, K.D. Artisanal Fishing: Promoting Poverty Reduction and Community Development through New WTO Rules on Fisheries Subsidies. An Issue and Options Paper; UNEP: Geneva, Switzerland, 2005, p. 50.

3. FAO. Strategies for Increasing the Sustainable Contribution of Small-Scale Fisheries to Food Security and Poverty Alleviation; Committee on Fisheries, Rome, Italy, 24-28 February 2003, COFI/2003/9; FAO: Rome, Italy, 2003.

4. FAO. Increasing the Contribution of Small-Scale Fisheries to Poverty Alleviation and Food Security; FAO Technical Guidelines for Responsible Fisheries No. 10; Rome, FAO, 2005; p. 79.

5. Marquette, C.M; Koranteng, K.A.; Overå, R.; Aryeetey, E.B.-D. Small-scale fisheries, population dynamics and resource use in Africa: The case of Moree, Ghana. Ambio 2002, 31, 324-336.

6. Lawson, R.M.; Kwei, E.A. African Entrepreneurship and Economic Growth: A Case Study of the Fishing Industry in Ghana; Ghana University Press: Accra, Ghana, 1974, p. 262.

7. Jorian, P. Going out or staying home: Seasonal movement and mitigation strategies among Xwla and Anlo-Ewe fisherman. MAST 1998, 1, 129-155. 
8. Amador, K.; Bannerman, P.; Quartey, R.; Ashong, R. Ghana Canoe Frame Survey; Report No. 34; Marine Fisheries Research Division, Ministry of Fisheries: Accra, Ghana, 2006; p. 43.

9. Atta Mills, J.; Alder, J.; Sumaila, R.U. The decline of a regional fishing nation: The case of Ghana and West Africa. Nat. Resour. Forum 2004, 28, 13-21.

10. Odotei, I. The Migration of Ghanaian Women in the Canoe Fishing Industry. MAST 1992, $5,88-95$.

11. KEEA. The Elmina 2015 Strategy: Building on the Past to Create a Better Future; A document prepared by the Komenda-Edina-Eguafo-Abrem (KEEA) District Assembly for the Elmina Cultural Heritage and Management Programme; KEEA District Assembly: Elmina, Ghana, 2003; p. 86.

12. Odotei, I. The Artisanal Marine Fishing Industry in Ghana: A Historical Overview; Legon, Institute of African Studies, University of Ghana: Accra, Ghana, 2002, p. 97.

13. World Gazetteer Online. Available online: http://bevoelkerungsstatistik.de/wg.php? $\mathrm{x}=117062325$ $3 \&$ men $=$ gcis $\& \operatorname{lng}=\mathrm{de} \&$ dat $=32 \& \mathrm{geo}=-85 \& \mathrm{srt}=\mathrm{npan} \& \mathrm{col}=\mathrm{aohdq} \& \mathrm{pt}=\mathrm{c} \& \mathrm{va}=\mathrm{x} \quad($ accessed $\quad$ on 23 July 2012).

14. Kwei, E.; Ofori-Adu, D.W. Fishes in the Coastal Waters of Ghana; Ronna Publishers: Tema, Ghana, 2005, p. 108.

15. Aheto, D.W. Valuation of Communal and Private Ownership of Mangrove Resources along the Western Coast of Ghana. In Culture, Science and Sustainable Development in Africa, First University of Cape Coast and University of Ilorin Joint Conference; Opoku-Agyeman, K., Ed.; University Press: Cape Coast, Ghana, 2011; pp. 464-477.

16. Lind, D.A.; Marchal, W.G.; Wathen, S.A. Statistical Techniques in Business and Economics, 12th ed.; McGraw-Hill Irwin: Boston, USA, 2005.

17. Hardin, G. The tragedy of the commons. Science 1968, 162, 1243-1248.

18. Gordon, H.S. The economic theory of a common property resource: The fishery. J. Polit. Econ. 1954, 62, 124-142.

19. Hilborn, R.; Quinn, T.P.; Schindler, D.E.; Rogers, D.E. Biocomplexity and fisheries sustainability. Proc. Natl. Acad. Sci. 2003, 100, 6564-6568.

(C) 2012 by the authors; licensee MDPI, Basel, Switzerland. This article is an open access article distributed under the terms and conditions of the Creative Commons Attribution license (http://creativecommons.org/licenses/by/3.0/). 